\title{
Effects of substrate and salinity in hydroponically grown Cichorium spinosum
}

\author{
E. Klados ${ }^{1}$, N.Tzortzakis ${ }^{2 *}$
}

${ }^{l}$ Department of Biological Greenhouse Crops and Floriculture, School of Agricultural Technology, Technological Education Institute of Crete, 71004 Heraklion, Greece. ${ }^{2}$ Department of Agricultural Science, Biotechnology and Food Science, Faculty of Geotechnical Sciences and Environmental Management, Cyprus University of Technology, 3603, Limassol, Cyprus.

*Corresponding author: nikolaos.tzortzakis@cut.ac.cy

\begin{abstract}
The present work, examined the effect of salinity $\left(5,40\right.$ and $\left.120 \mathrm{mmol} \mathrm{L}^{-1} \mathrm{NaCl}\right)$ in the growth and the quality of hydroponic culture of stamnagathi (Cichorium spinosum L.). Plants were developed in perlite, pumice, rockwool and sand respectively. High salinity decreased leaf number, leaf size and plant biomass in plants grown in perlite, pumice and sand. Reduced plant biomass also observed in plant grown in rockwool, although an increased number of leaves were produced. Leaf area reduced in plants grown in rockwool and sand under $120 \mathrm{mmol} \mathrm{L}^{-1} \mathrm{NaCl}$. Low salinity maintained almost similar status as the control treatments. Symptoms of tip burn appeared in $120 \mathrm{mmol}$ $\mathrm{L}^{-1} \mathrm{NaCl}$ treated stamnagathi for perlite and pumice. No differences observed in leaf chlorophyll content, leaf fluorescence and in symptoms of discoloration. When the perlite was used as substrate, salinity increased total phenols and decreased protein content. Finally, the low concentration of salinity improved some plant quality parameters as recorded by panelists, following organoleptic test. Thus, stamnagathi proved to successfully tolerate low salinity concentration in hydroponically grown plants.
\end{abstract}

Keywords: Agronomic performance, growth, salt stress, soilless culture, stamnagkathi

\section{Introduction}

Saltwater intrusion is one of the major environmental problems in many Mediterranean agricultural areas due to the irreversible effects on the quality of the water used for irrigation purposes. Large quantities of fresh water supplies are expected to be diverted from agriculture to the growing water demand in municipal and industrial sectors in the region (Hamdi et al., 1995;
Correia, 1999). Indeed, use of marginal quality water (brackish, reclaimed, drainage) is necessary but may causes an increase of soil salinity, which may have negative effects on growth and yield of crops. Thus, the use of semi-saline underground water by growers causes a gradual build-up of $\mathrm{Na}^{+}$and $\mathrm{Cl}^{-}$in the root zone (Sonneveld, 2000). An efficient way to overcome 
salinity problems is the introduction of salt tolerance to crops. The tolerance or sensitivity may differ according to the type of salinity, the different species, the culture medium and the plant growth stage (Botia et al., 1998). Exposure to $\mathrm{NaCl}$ salinity affects the water and ion transport processes in plant, that may affect the nutritional status and ion balance (Liu and Van Staden 2001) as well as physiological processes (Munns and Termaat, 1986; Savvas and Lenz, 1994). High concentration of salts causes ion imbalance and hyperosmotic stress in plants. Furthermore, an important consequence of salinity stress in plants is the excessive generation of harmful reactive oxygen species (ROS), such as superoxide anion $\left(\mathrm{O}_{2}^{-}\right)$, hydrogen peroxide $\left(\mathrm{H}_{2} \mathrm{O}_{2}\right)$ and the hydroxyl radicals $\left(\mathrm{OH}^{-}\right)$particularly in chloroplasts and mitochondria (Mittler, 2002). Previous studies reported the tolerance and the effects of salt on greenhouse grown vegetables, including hydroponically grown crops (Savvas and Lenz, 1994; Pardossi et al., 1999; Chartzoulakis and Klapaki, 2000; Tzortzakis, 2009; Chondraki et al., 2012), but gaps in the knowledge exist.

It has been proposed that a possible solution to the salinity problem is to select edible plant species capable of utilizing sufficiently high concentrations of $\mathrm{NaCl}$, which exhibit high productivity. Salicomia europaea L., glasswort, is one of the most promising candidates to be included in the human diet. This plant is capable of accumulating up to $50 \% \mathrm{NaCl}$ (dry basis) (Ushakova et al., 2005). Vegetables are cultivated extensively in Crete, as well as in coastal areas through the Mediterranean region where groundwater with high salt $\mathrm{Na}^{+}$and $\mathrm{Cl}^{-}$content, due to sea water intrusion, is commonly used to irrigate vegetables (Chartzoulakis and Klapaki, 2000).

Cichorium spinosum (L.) is very popular as a leafy vegetable not only in Crete but also in other parts of Greece and Mediterranean countries, while it reaches very high prices in the fresh vegetable market, with important nutritive value and antioxidants (Meliou et al., 2003; Zeghichi et al., 2003; Simopoulos, 2004). Therefore, its cultivation has a potential to be expanded in the coming years. It is well adapted in fields with low soil fertility and is characterized by minimal cultivation needs. Most of the available fields with these characteristics in Crete are located close to coastal areas and suffer from salinity. Therefore, knowledge on the responses of this crop to salinity is very important in improving its performance and planning new areas for its expansion. However, up to date, there is no any information regarding the salt tolerance of $C$. spinosum. This study was undertaken to investigate to what extent salinity affected plant growth and yield as well as the impact of substrate medium in hydroponically grown C. spinosum, which is known as "stamnagathi" in Crete.

\section{Materials and Methods}

\subsection{Experimental design}

Stamnagathi plants were grown under natural light during spring in an unheated plastic greenhouse, in Crete, Greece. Average minimum and maximum air temperatures during this period were 16 and 32 ${ }^{\circ} \mathrm{C}$, respectively. Four substrates, perlite, pumice, rockwool and sand as well as three level of salinities (5, 40 and $\left.120 \mathrm{mmol} \mathrm{L}^{-1} \mathrm{NaCl}\right)$ were used to create twelve treatments which were: 1-3) Perlite (5, 40 and $120 \mathrm{mmol} \mathrm{L}^{-1} \mathrm{NaCl}$ ); 4-6) Pumice (5, 40 and $120 \mathrm{mmol}$ $\left.\mathrm{L}^{-1} \mathrm{NaCl}\right)$; 7-9) Sand (5, 40 and $\left.120 \mathrm{mmol} \mathrm{L}^{-1} \mathrm{NaCl}\right)$; 10-12) Rockwool (5, 40 and $\left.120 \mathrm{mmol} \mathrm{L}^{-1} \mathrm{NaCl}\right)$.

Plants were purchased from a local nursery at a stage of 7-8 leaves and directly transplanted in the substrates. Each salinity treatment consisted of 3 individual rows on a greenhouse trough ( 9 in total). In each trough, each substrate (of the 4 substrates) were arranged in two 16 L capacity bags ( 5 plants in each bag), with 8 bags/ row. Thus a total number of 30 plants per substrate/ salinity were used. Rows were $1.0 \mathrm{~m}$ apart and plants were separated in bags by $0.2 \mathrm{~m}$, which is the standard practice for plants with little biomass volume in greenhouse production. Drip irrigation emitters (four 
emitters/bag) were placed at the top of each bag, which had slits in the bottom to allow drainage. Before transplanting, the bags were soaked with a full strength nutrient solution, made using commercial fertilizers with $1.44 \mathrm{~N}-0.25 \mathrm{P}-1 \mathrm{~K}$ a.i. (v/v/v) content. Perlite, pumice, rockwool and sand were obtained from Lava (Yali, Greece) and local supplier.

The soilless culture system employed in the present study was open system with the excess nutrient solution drained away. A solution $(1: 100 \mathrm{v} / \mathrm{v})$ in water containing the following concentration of nutrients: $\mathrm{NO}_{3}^{-}-\mathrm{N}=14.19, \mathrm{~K}=9.21, \mathrm{PO}_{4}-\mathrm{P}=0.97$, $\mathrm{Ca}=3.74, \mathrm{Mg}=2.88, \mathrm{SO}_{4}^{-2}-\mathrm{S}=1.56$ and $\mathrm{Na}=1.30$ mmol L ${ }^{-1}$, respectively; and $\mathrm{B}=18.52, \mathrm{Fe}=71.53$, $\mathrm{Mn}=18.21, \mathrm{Cu}=4.73, \mathrm{Zn}=1.52$, and $\mathrm{Mo}=0.52$ $\mu \mathrm{mol} \mathrm{L}{ }^{-1}$, respectively. Fertigation was applied during the daytime through a timer (3-5 min every $4 \mathrm{~h}$ at a flow rate of $25 \mathrm{~mL} \mathrm{~min}^{-1}$ ) with a drip irrigation system (via emitters) by means of pressure pumps. Nutrient solution target $\mathrm{pH}$ and $\mathrm{EC}$ were 5.9 and $2.1 \mathrm{dS} \mathrm{m}^{-1}$ respectively. The saline solutions were prepared with tap water containing $5 \mathrm{mmol} \mathrm{L}^{-1} \mathrm{NaCl}$. To avoid osmotic shock $\mathrm{NaCl}$ was applied in stepped up daily increments of approximately $10 \mathrm{mmol} \mathrm{L}^{-1}$ until the final concentration was reached.

\subsection{Plant growth and development}

Beginning second week after transplanting, it was studied the impact of substrate medium and salinity level on plant growth/development and yield. Weekly, it was measured the leaf number and leaf length. Additionally, the levels of chlorophyll and fluorescence of the leaf determined (Minolta SPAD and Chlorophyll fluorometer -Optisciences OS-30p, Herts, UK) while measurements were carried out between 9:00 11:10AM. Macroscopic assessment on discoloration and tip-burn (score 1-5; 1-bad, 2-medium, 3-good, 4-very good, 5-excellent) was also determined.

At the end of the experiment, fresh weight and dry matter content (\%) of plant upper part and leaf area produced were measured. In order to examine a putative salt build up, the $\mathrm{pH}$ and $\mathrm{EC}$ values of nutrient drainage assessed employing a portable $\mathrm{pH} / \mathrm{EC}$-meter (HI 98130 HR, Hanna Instruments, USA) for each treatment.

\subsection{Salinity in conjunction to perlite medium used}

A case study with perlite as inert material and salinity levels $\left(5,40\right.$ and $\left.120 \mathrm{mmol} \mathrm{L}^{-1} \mathrm{NaCl}\right)$, conducted for the evaluation of the total phenolics (as described previously in Tzortzakis et al., 2007) and total protein content as well as the 1-Dimensional protein profile. For protein extraction, the frozen tissue samples were pulverized to a powder in liquid nitrogen with a mortar and pestle. The powder was mixed with the extraction buffer, which contained: $100 \mathrm{mmol} \mathrm{L}^{-1}$ Tris- $\mathrm{HCl} \mathrm{pH} 8,2 \mathrm{mmol} \mathrm{L}^{-1}$ EDTA, 3 mmol L-1 $\mathrm{MgCl}_{2}$, $0.2 \%$ Glycerol, $0.2 \%$ Triton $\mathrm{X} 100$ and $5 \mathrm{mmol} \mathrm{L}^{-1}$ DTT. After homogenization in an Ultra-Turrax (T25 digital ultra-turrax, IKA, Germany; three times, 30 sec each) and incubation on ice for $15 \mathrm{~min}$, debris was removed by centrifugation using a Sigma laboratory 4K15 centrifuge at $12,000 \mathrm{~g}$ for $20 \mathrm{~min}$ and the supernatants were used for protein determination. All steps were carried out at $4{ }^{\circ} \mathrm{C}$. The protein content of the extracts was determined following trichloroacetic acid (TCA) precipitation by the method of Lowry et al. (1951) with bovine serum albumin as the protein standard measuring absorbance at $625 \mathrm{~nm}$. Sodium dodecyl sulfate polyacrylamide gel electrophoresis (SDS-PAGE) was carried out (3 gels in total) using the Bio-Rad mini Protean II Dual Slab Cells gel apparatus, was performed on $10 \%$ acrylamide gels, as previously described (Loulakakis et al., 1994).

Additionally, an organoleptic assessment took place at the end of the experiment. Sixteen panelists (9 female and 7 male; averaged 21 to 38 years old; with variable educational status) were subsequently invited to assess (questionnaires with 10 multiple choice questions) samples in terms of appearance, color, size, texture, taste and marketability using scales (values of acceptance) with anchor points 1: 'poor/bad/pit' and 5: 'excellent/sweet'. Scales were converted to percentage 
values. Individual panelists were presented with a plate containing two whole plants and five to six leaves for the sensory analysis. Panel tests were conducted in isolation in booths in the same room to prevent interchange between panel members and all tests conducted under the same conditions and without time limit.

\subsection{Statistical analysis}

The experiment was carried out twice (excluding the impacts of salinity in conjunction to perlite medium used). Percentage data were log-transformed before analysis. Data were tested for normality, and then subjected to Analysis of Variance (ANOVA). Significant differences between mean values were determined using Duncan's Multiple Range test
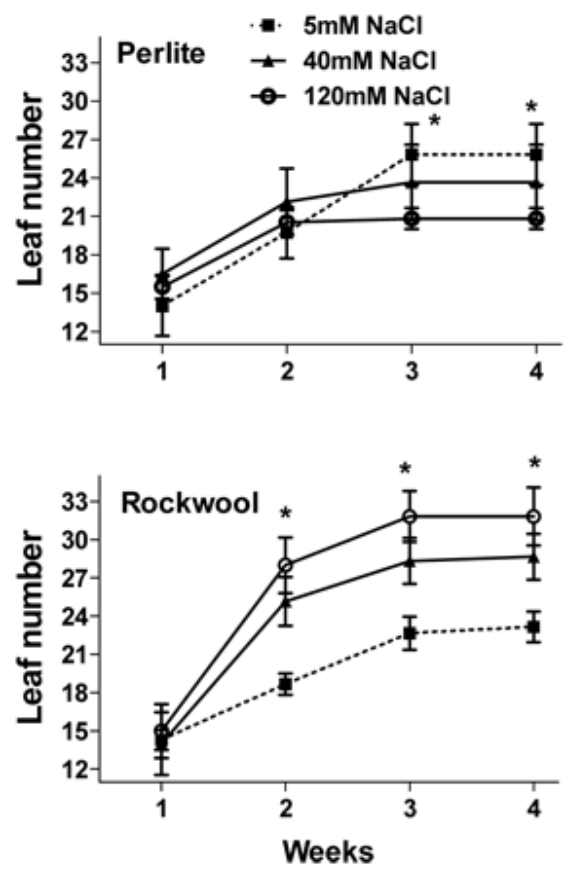

$(p<0.05)$ following one-way ANOVA. Statistical analyses were performed using SPSS (SPSS Inc., Chicago, Ill.).

\section{Results}

\subsection{Plant growth}

ANOVA indicated that the number of leaves produced was affected by substrate medium and/or $\mathrm{NaCl}$ concentration when different inert substrates used for stamnagathi culture (Figure 1). Salinity at high (120 mmol L ${ }^{-1} \mathrm{NaCl}$ ) levels decreased (up to $19 \%$ and $28 \%$ respectively) leaf number in plants grown in perlite and pumice comparing with the control treatment while no differences observed between low $(40 \mathrm{mmol}$ $\mathrm{L}^{-1} \mathrm{NaCl}$ ) salinity and control.
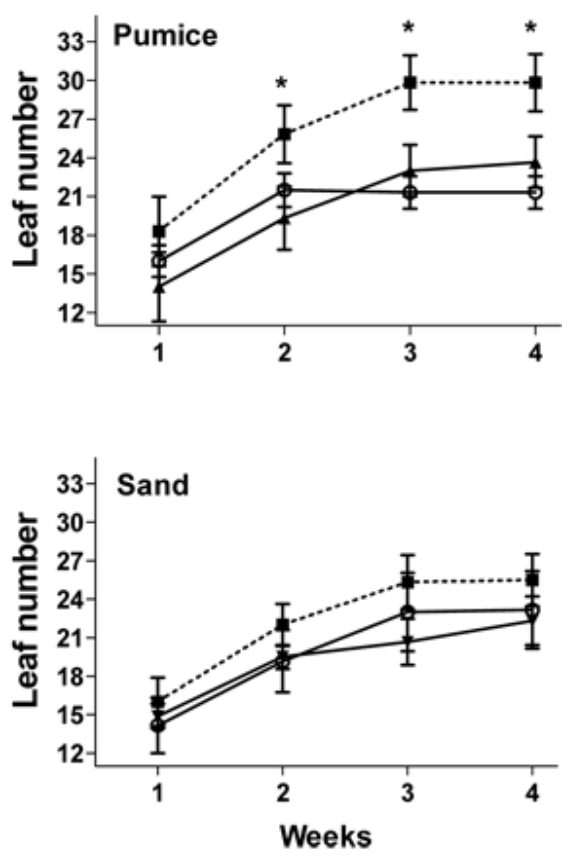

Figure 1. Influence of $\mathrm{NaCl}$ salinity $(5 \mathrm{mM}, 40 \mathrm{mM}$ and $120 \mathrm{mM})$ and substrate medium on leaf number produced in hydroponically grown stamnagkathi in an open system. Values represent mean $( \pm \mathrm{SE})$ of measurements made on six plants per treatment. Star symbol refers to significant differences at $p=0.05$, following one-way ANOVA. 
The oppose results obtained when plants grown in rockwool under different salinity levels as the increased salinity concentration increased (up to $26 \%$ ) leaf number. No differences in leaf number observed in plants grown in sand substrate under salinity. Examining the performance of control treatments under different inert medium, the best performance obtained in plant grown in pumice (30 leaves) and the worst one in plants grown in rockwool (23 leaves). Regarding leaf length, plants grown in $40 \mathrm{mmol} \mathrm{L}^{-1}$ $\mathrm{NaCl}$ marked an increased trend (but not statistically different) for longer size leaves when plants grown in perlite, pumice and sand while the oppose phenomenon took place in case of rockwool when used as substrate (Figure 2). Indeed, higher salinity levels reduced (up to $15 \%$ ) leaf length in plants grown in perlite, pumice and rockwool. Examining the impacts of substrate medium on leaf length produced, the longer leaves produced in rockwool (averaged $16.3 \mathrm{~cm}$ ), followed by perlite (averaged $14.7 \mathrm{~cm}$ ), pumice (averaged $13.4 \mathrm{~cm}$ ) and sand (averaged $11.6 \mathrm{~cm}$ ). Similar outcomes observed when plant diameter measured (data not shown)
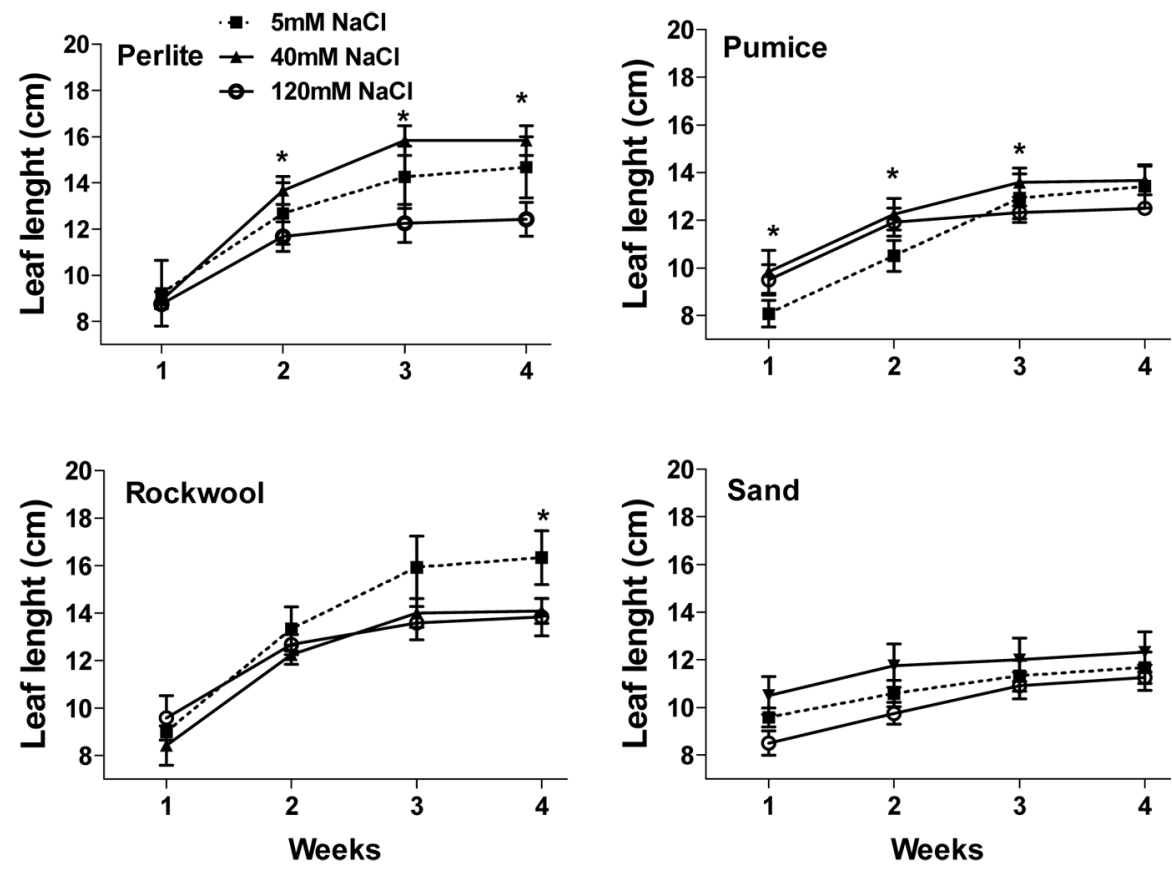

Figure 2. Influence of $\mathrm{NaCl}$ salinity $(5 \mathrm{mM}, 40 \mathrm{mM}$ and $120 \mathrm{mM}$ ) and substrate medium on leaf length (in $\mathrm{cm}$ ) number produced in hydroponically grown stamnagkathi in an open system. Values represent mean $( \pm \mathrm{SE})$ of measurements made on six plants per treatment. Star symbol refers to significant differences at $p=0.05$, following one-way ANOVA. 
Table 1. Influence of $\mathrm{NaCl}$ salinity ( $5 \mathrm{mM}$-control, $40 \mathrm{mM}$ and $120 \mathrm{mM}$ ) and substrate medium on upper plant fresh weight (g), upper plant dry matter (\%), leaf area produced ( $\mathrm{cm}^{2} /$ plant), tip burn (scale 1-5) and leaf fluorescence in hydroponically grown stamnagkathi in an open system. Means were compared by Duncan's Multiple Range Test. Values $(\mathrm{n}=6)$ in columns followed by the same letter for each individual substrate are not significantly different, $p<0.05$.

\begin{tabular}{lllllll}
\hline & $\begin{array}{l}\text { NaCl } \\
(\mathbf{m M})\end{array}$ & $\begin{array}{l}\text { Upper } \\
\text { FWt }(\mathbf{g})\end{array}$ & $\begin{array}{c}\text { Upper dry } \\
\text { matter }(\%)\end{array}$ & $\begin{array}{l}\text { Leaf area } \\
\left(\mathbf{c m}^{2} / \mathbf{p l a n t}\right)\end{array}$ & $\begin{array}{l}\text { Tip } \\
\text { burn }\end{array}$ & $\begin{array}{l}\text { Fluorescen } \\
\mathbf{c e}(\mathbf{F v} / \mathbf{F m})\end{array}$ \\
\hline Perlite & 5 & $18.9 \mathrm{a}$ & $12.6 \mathrm{~b}$ & $173.6 \mathrm{a}$ & $5.0 \mathrm{a}$ & $0.83 \mathrm{a}$ \\
& 40 & $12.5 \mathrm{~b}$ & $16.1 \mathrm{a}$ & $180.8 \mathrm{a}$ & $5.0 \mathrm{a}$ & $0.84 \mathrm{a}$ \\
& 120 & $11.6 \mathrm{~b}$ & $16.8 \mathrm{a}$ & $174.5 \mathrm{a}$ & $4.3 \mathrm{~b}$ & $0.85 \mathrm{a}$ \\
& & & & & & \\
Pumice & 5 & $17.4 \mathrm{a}$ & $14.2 \mathrm{c}$ & $234.1 \mathrm{a}$ & $4.9 \mathrm{a}$ & $0.83 \mathrm{a}$ \\
& 40 & $13.2 \mathrm{~b}$ & $16.1 \mathrm{~b}$ & $187.6 \mathrm{a}$ & $4.9 \mathrm{a}$ & $0.85 \mathrm{a}$ \\
& 120 & $11.4 \mathrm{~b}$ & $18.8 \mathrm{a}$ & $225.1 \mathrm{a}$ & $4.3 \mathrm{~b}$ & $0.84 \mathrm{a}$ \\
& & & & & & \\
Rockwool & 5 & $18.1 \mathrm{a}$ & $13.0 \mathrm{a}$ & $221.2 \mathrm{a}$ & $5.0 \mathrm{a}$ & $0.84 \mathrm{a}$ \\
& 40 & $12.4 \mathrm{~b}$ & $13.9 \mathrm{a}$ & $147.3 \mathrm{~b}$ & $4.9 \mathrm{a}$ & $0.84 \mathrm{a}$ \\
& 120 & $13.3 \mathrm{~b}$ & $13.7 \mathrm{a}$ & $189.5 \mathrm{ab}$ & $5.0 \mathrm{a}$ & $0.85 \mathrm{a}$ \\
& & & & & & \\
\hline \multirow{2}{*}{ Sand } & 5 & $9.9 \mathrm{a}$ & $19.3 \mathrm{a}$ & $157.8 \mathrm{a}$ & $5.0 \mathrm{a}$ & $0.84 \mathrm{a}$ \\
& 40 & $7.7 \mathrm{a}$ & $17.7 \mathrm{~b}$ & $113.4 \mathrm{ab}$ & $5.0 \mathrm{a}$ & $0.84 \mathrm{a}$ \\
& 120 & $6.4 \mathrm{~b}$ & $17.7 \mathrm{~b}$ & $96.3 \mathrm{~b}$ & $4.7 \mathrm{a}$ & $0.83 \mathrm{a}$ \\
\hline
\end{tabular}

Plant biomass (plant upper part) reduced in both (40 mmol L-1 and $120 \mathrm{mmol} \mathrm{L}^{-1} \mathrm{NaCl}$ ) salinity levels for perlite (up to $39 \%$ ), pumice (up to $34 \%$ ) and rockwool (up to $31 \%$ ) while this was marked only for the 120 mmol L ${ }^{-1} \mathrm{NaCl}$ application in case of the sand (Table 1). The increase of the salinity levels resulted in increased dry matter content for plants grown in perlite and pumice while the reverse took place in case of sand used as substrate. No differences in plant dry matter content marked in case plants grown in rockwool in different saline levels. Leaf area reduced in $120 \mathrm{mmol} \mathrm{L}^{-1} \mathrm{NaCl}$ treated plants grown in sand (up to $39 \%$ ) and in $40 \mathrm{mmol}$ $\mathrm{L}^{-1} \mathrm{NaCl}$ treated plants grown in rockwool (up to $33 \%$ ).
Due to macroscopic evaluation, symptoms of tip burn appeared in $120 \mathrm{mmol} \mathrm{L}^{-1} \mathrm{NaCl}$ treated stamnagathi for perlite and pumice while no symptoms obtained in case of rockwool and sand used as substrates (Table 1). No symptoms of discoloration obtained among different treatments. Leaf chlorophyll content and leaf fluorescence were not affected by treatment, i.e., leaf chlorophyll averaged 70.1 SPAD units and leaf fluorescence averaged $0.84 \mathrm{Fv} / \mathrm{Fm}$.

The $\mathrm{pH}$ in nutrient drainage did not change among the different levels of salinity and/or substrate used. However, the EC values of nutrient drainage increased 
as salinity levels increased and reached 2.57 and 3.04 $\mathrm{dS} \mathrm{m}{ }^{-1}$ for perlite, 2.48 and $3.45 \mathrm{dS} \mathrm{m}^{-1}$ for pumice, 2.25 and $3.12 \mathrm{dS} \mathrm{m}^{-1}$ for rockwool and 2.41 and $3.12 \mathrm{dS} \mathrm{m}^{-1}$ for sand for $40 \mathrm{mmol} \mathrm{L}^{-1} \mathrm{NaCl}$ and $120 \mathrm{mmol} \mathrm{L}^{-1} \mathrm{NaCl}$ respectively, comparing with control treatment that $\mathrm{EC}$ averaged of $1.77 \mathrm{dS} \mathrm{m}^{-1}$.

\subsection{Salinity affected stamnagathi grown on perlite}

High $\left(120 \mathrm{mmol} \mathrm{L}^{-1} \mathrm{NaCl}\right)$ salinity application increased (up to $42 \%$ ) total phenol content in plants grown in perlite while no differences observed in $40 \mathrm{mmol} \mathrm{L}^{-1}$ $\mathrm{NaCl}$ application (Table 2). The oppose phenomenon took place regarding the content of proteins. In details, total protein content reduced (up to 17\%) in $120 \mathrm{mmol}$ $\mathrm{L}^{-1} \mathrm{NaCl}$ treated plants which is presented as well in the one dimension protein content analysis (Figure 3). In each of the 3 wells of the gel were placed leaf extract of plants grown at different $\mathrm{NaCl}$ concentrations. The bands were formed by different proteins. The effect of $\mathrm{NaCl}$ on soluble proteins can be judged by the color intensity of the bands. In general, certain protein bands at the higher concentrations of $\mathrm{NaCl}$ seem to be lighter than those at the lower concentrations. However, a more detail analysis is required in order to identify specific proteins groups and sequencing that altered due to salinity effects.

Table 2. Influence of $\mathrm{NaCl}$ salinity ( $5 \mathrm{mM}$-control, 40 $\mathrm{mM}$ and $120 \mathrm{mM}$ ) in the content of total phenolics ( $\mu \mathrm{mol}$ $\mathrm{GAE} / 100 \mathrm{~g}$ fresh weight) and total protein (mg/g fresh weight) in hydroponically grown stamnagkathi in an open system. Means were compared by Duncan's Multiple Range Test. Values $(n=6)$ in columns followed by the same letter are not significantly different, $p<0.05$.

\begin{tabular}{lll}
\hline & $\begin{array}{l}\text { Total Phenols } \\
(\mu \mathrm{mol} \text { GAE/100g FWt })\end{array}$ & $\begin{array}{l}\text { Total Proteins } \\
(\mathrm{mg} / \mathrm{g} \mathrm{FWt})\end{array}$ \\
\hline $5 \mathrm{mM} \mathrm{NaCl}$ & $145.6 \mathrm{~b}$ & $4.81 \mathrm{a}$ \\
$40 \mathrm{mM} \mathrm{NaCl}$ & $212.7 \mathrm{ab}$ & $4.35 \mathrm{ab}$ \\
$120 \mathrm{mM} \mathrm{NaCl}$ & $251.5 \mathrm{a}$ & $3.97 \mathrm{~b}$ \\
\hline
\end{tabular}

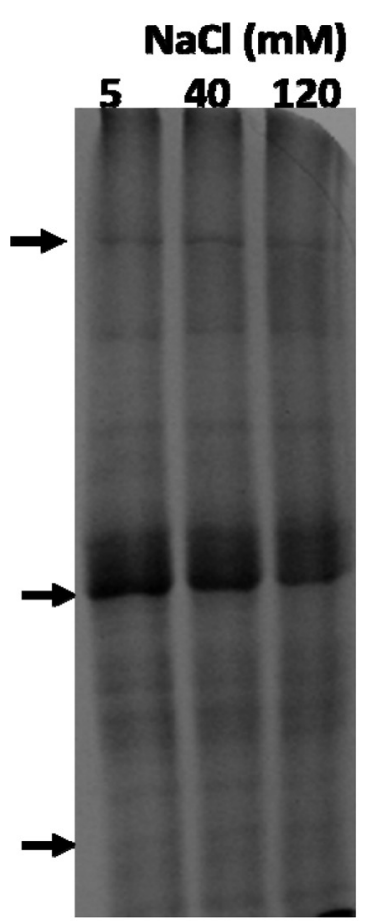

Figure 3. Impacts of $\mathrm{NaCl}$ salinity $(5 \mathrm{mM}, 40 \mathrm{mM}$ and $120 \mathrm{mM}$ ) on protein content (protein electrophoresis gels) of leaf extracts of hydroponically grown stamnagkathi in perlite in an open system. SDS-PAGE gels were Coomassie Brilliant Blue R-250 stained. Arrows indicate shifts in proteins.

Following the organoleptic assessment, all panelists could found differences among samples and assessed that stamnagathi plants grown in perlite in high (120 mmol L-1 $\mathrm{NaCl}$ ) salinity decreased appearance and acceptability but increased bitterness comparing to control and low $\left(40 \mathrm{mmol} \mathrm{L}^{-1} \mathrm{NaCl}\right)$ salinity treatments (Table 3), while no differences observed among control and low salinity treatments. Indeed, both saline levels accelerated plant tissue hardness and sourness comparing with the control treatment. No differences observed in plant color and size among different treatments. Additionally, regarding marketability/ attractiveness for buying of the stamnagathi, it was 
assessed as $19 \%$ 'sometimes', $25 \%$ 'rather yes' and $56 \%$ 'yes' for the control plants; as 6\% 'rather no', $19 \%$ 'sometimes', $31 \%$ 'rather yes' and $44 \%$ 'yes' for the $40 \mathrm{mmol} \mathrm{L}^{-1} \mathrm{NaCl}$ treated plants; and 6\% 'no', $25 \%$ 'sometimes', $44 \%$ 'rather yes' and $25 \%$ 'yes' for the $120 \mathrm{mmol} \mathrm{L}^{-1} \mathrm{NaCl}$ treated plants.

Table 3. Influence of $\mathrm{NaCl}$ salinity (5 mM-control, $40 \mathrm{mM}$ and $120 \mathrm{mM}$ ) in organoleptic attributes of appearance, color, size, bitterness, hardness, sourness and acceptability in hydroponically grown Stamnagkathi in perlite in an open system. Means were compared by Duncan's Multiple Range Test. Values $(n=16)$ in columns followed by the same letter are not significantly different, $p<0.05$.

\begin{tabular}{llllllll}
\hline & Appearance & Color & Size & Bitterness & Hardness & Sourness Acceptability \\
\hline $5 \mathrm{mM} \mathrm{NaCl}$ & $71.2 \mathrm{a}$ & $80.1 \mathrm{a}$ & $73.7 \mathrm{a}$ & $52.1 \mathrm{~b}$ & $53.7 \mathrm{~b}$ & $52.5 \mathrm{~b}$ & $77.5 \mathrm{a}$ \\
$40 \mathrm{mM} \mathrm{NaCl}$ & $71.5 \mathrm{a}$ & $80.3 \mathrm{a}$ & $70.1 \mathrm{a}$ & $52.5 \mathrm{~b}$ & $57.5 \mathrm{a}$ & $57.5 \mathrm{a}$ & $73.7 \mathrm{a}$ \\
$120 \mathrm{mM} \mathrm{NaCl}$ & $67.5 \mathrm{~b}$ & $82.6 \mathrm{a}$ & $73.2 \mathrm{a}$ & $56.9 \mathrm{a}$ & $57.8 \mathrm{a}$ & $56.2 \mathrm{a}$ & $69.8 \mathrm{~b}$ \\
\hline
\end{tabular}

Sample assessment performed by using scales (values of acceptance) with anchor points 1: 'Poor/bad/pit' and 5: 'excellent/sweet'. Scales were converted to percentage values.

\section{Discussion}

Salinity is one of the major abiotic stresses affecting plant productivity. The plant growth and yield responded differently to salinity as result of various salt effects, including growth limitations derived by nutritional imbalances (Grattan and Grieve, 1999; Song et al., 2006), reduced carbon fixation due to specific ion toxicity (Niu et al., 1995), restriction of photosynthesis due to partial stomata closure, waste of energy in the processes of osmotic adaptation and ion exclusion (Di Martino et al., 2003). Developments in plant breeding and selection in conjunction with soil and water management, as well as irrigation and drainage technologies enhance and facilitate the use of low quality water for irrigation with minimum adverse impacts on soil productivity and the environment (Chartzoulakis and Klapaki,
2000). It is, therefore, possible to mitigate the adverse effects of salinity, if the specific mechanisms involved in the salt tolerance of each cultivated species are well known.

In the present study, stamnagathi treated with up to $120 \mathrm{mmol} \mathrm{L}^{-1} \mathrm{NaCl}$, grown hydroponically, affected the upper plant biomass by reducing leaf number and leaf length as a consequence reduced plant biomass being in accordance with De Pascale and Barbieri (1995) when salinity $\left(>2.0\right.$ and $\left.2.6 \mathrm{dS} \mathrm{m}^{-1}\right)$ applied in lettuce (Lactuca sativa L.). Other studies reported that lettuce and parsley (Petroselinum crispum Mill) leaf number and leaf dry weight reduced by salinity treatments (Pardossi et al., 1999; Andriolo et al., 2005; Chondraki et al., 2012). The leaf/root ratio in lettuce, endive (Cichorium intybus L.) and celery [Apium graveolens L. var. dulce (Mill.) Pers.] was reduced as 
salinity increased (Pardossi et al., 1999; Tzortzakis, 2009). However, it has been reported, that leaf weight increased with salinity (thicker leaves) on tomato (Solanum Lycopersicum L.; Hayward and Long, 1941), bean (Phaseolus vulgaris L.) (Gama et al., 2007) and eggplant (Solanum melongena L.) (Shalhevet et al., 1993), which differ from the present outcomes, and this may be related to plant species and/or salt concentration adaption. Wignarajah et al. (1975) reported that in beans high $\mathrm{NaCl}$ levels inhibited leaf expansion, largely due to an inhibition of cell division rather than to cell expansion (Chartzoulakis and Klapaki, 2000).

Moreover, plant growth affected by substrate medium with good performance in perlite and pumice followed by rockwool and sand (Figure 4). Throughout the world, the raw materials used vary based on their local availability. Such raw materials can be inorganic or organic, but growing media are often formulated from a blend of different raw materials in order to achieve the correct balance of air and water holding capacity for the plants to be grown as well as for the long-term stability of the medium (Nair et al., 2011).

Several factors determine the type of growing medium appropriate for specific growing conditions. Although crop performance (yield and quality) is usually the primary factor in developing a growing medium, other traits such as cost, re-use or recycling potentials are critical for a sustainable production system. Thus, perlite and pumice are locally available material and environmental friendly used comparing with the rockwool (i.e. disposal issues). For that reason, the perlite medium used as substrate for further determination in the current study.

In plants grown in perlite, the total phenol content increased with high $\left(120 \mathrm{mmol} \mathrm{L}^{-1} \mathrm{NaCl}\right)$ salinity application while no differences observed in $40 \mathrm{mmol} \mathrm{L}^{-1} \mathrm{NaCl}$ application. Adverse effects observed for the content of proteins. Thus, high salinity causes severe damage to plants, including growth inhibition, impaired metabolism, necrosis, loss of production and quality as well as imbalance of nutrients in plant (Song et al., 2006). The imbalance caused by salinity affects the nutrients involved in protein synthesis and photosynthesis, which can lead to inhibition of these processes as well as pigments chlorophyll a and b (Di Martino et al., 2003).

Increased salinity generally reduces vegetable yield, but it may improve quality (as in the present study whereas total phenols increased under high salinity), as observed in plants grown in both soil and soilless culture (Francois, 1994; Pardossi et al., 1999). Inhibition of vegetative growth and yield in pepper (Capsicum annuum L.) at high salinity levels is associated with marked inhibition of photosynthesis (Chartzoulakis and Klapaki, 2000) because it reduced assimilation of photosynthate, possibly a consequence of reduced uridine diphosphoglucose (UDPG), uridine triphosphate (UTP) and adenosine triphosphate (ATP) pools in growing leaves (Nieman et al., 1988).

Following organoleptic test, low salinity maintained appearance and acceptability and increased plant tissue hardeness and sourness comparing with the control treatment, which is quality-related characteristic for stamnagathi plants. No differences obtained in color macroscopically, which is in agreement with the findings leaf chlorophyll content measured instrumentally.

In hydroponically-grown tomato plants increasing salinity of the nutrient solution increased concentration of dry matter, sugars and organic acids in fruit, and provided the basis for better taste and higher firmness (Petersen et al., 1998). 

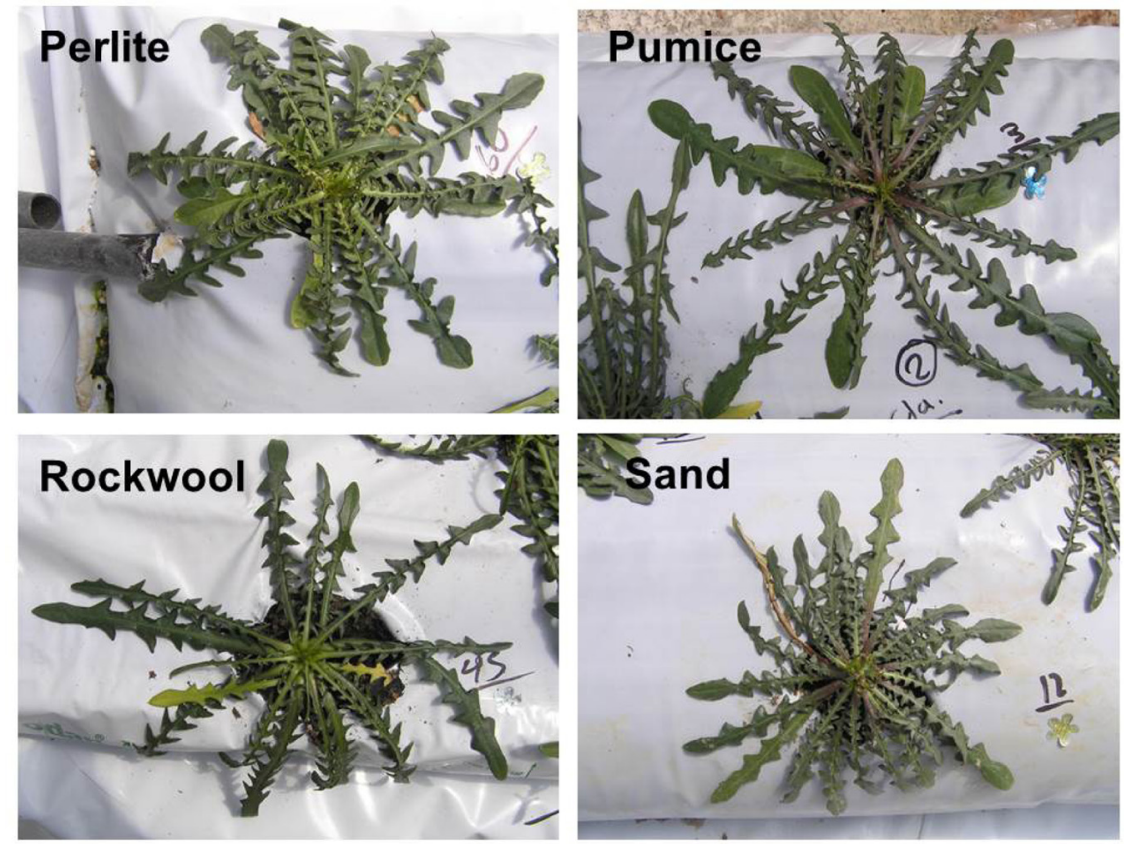

Figure 4. Phenotypic presentation of the hydroponically grown stamnagkathi in perlite, pumice, rockwool and sand, in an open system.

\section{Conclusions}

To overcome water shortages, and to satisfy the increasing water demand for agricultural development, alternative uses of marginal quality water will become necessary in many countries. The present study highlights that low salinity concentration may be used successfully in hydroponically grown plants employ perlite and/or pumice as substrate medium. Further study required in order to understand how salts affect soil/substrate characteristics and plant performance. In order to minimize water and nutrient solution waste after drainage during crop cultivation, a close hydroponic system with nutrient recirculation could be examined in future.

\section{References}

Andriolo, J.L., da Luz, G.L., Witter, M.H., Godoi, R. S., Barros, G.T., Bortolotto, O.C. 2005. Growth and yield of lettuce plants under salinity. Hortic. Bras. 23, 931-934.

Botia, P., Carvajal, M., Cerda, A., Martinez, V. 1998. Response of eight Cucumis melo cultivars to salinity during germination and early vegetative growth. Agronomie. 18, 503-513.

Chartzoulakis, K., Klapaki, G. 2000. Response of two greenhouse pepper hybrids to $\mathrm{NaCl}$ salinity during different growth stages. Sci. Hortic. 86, 247-260.

Chartzoulakis, K., Loupassaki, M., Bertaki, M., Androulakis, I. 2002. Effects of $\mathrm{NaCl}$ salinity on 
growth, ion content and $\mathrm{CO}_{2}$ assimilation rate of six olive cultivars. Sci. Hortic. 96, 235-247.

Chondraki, S., Tzerakis, C., Tzortzakis, N. 2012. Influence of $\mathrm{NaCl}$ and calcium foliar spray on hydroponically grown parsley in NFT system. J. Plant Nutr. 35, 1457-1467.

Correia, F.N. 1999. Water resources in the Mediterranean region. Water Int. 24, 22-30.

De Pascale, S., Ruggiero, C., Barbieri, G. 2003. Physiological responses of pepper to salinity and drought. J. Am. Soc. Hortic. Sci. 128, 48-54.

Di Martino, C., Sebastiano, D., Pizzuto, R., Loreto, F., Fyggi, A. 2003. Free amino acids and glycine betaine in leaf osmoregulation of spinach responding to increasing salt stress. New Phytologist, 158, 455-463.

Francois, L.E., Maas, E.V. 1994. Crop response and management of salt-affected soils. In: Pessarakli, M. (Ed.), Handbook of Plant and Crop Stress, Marcel Dekker, New York, pp. 449-459.

Gama, P.B.S., Inanaga, S., Tanaka, K., Nakazawa, R. 2007. Physiological response of common bean (Phaseolus vulgaris L.) seedlings to salinity stress. African J. Biotechnol. 6, 79-88.

Grattan, S.R., Grieve, C.M. 1999. Salinity - mineral nutrient relations in horticultural crops. Sci. Hortic. 78, 127- 157.

Hamdi, A., Abu-Zeid, M.F., Lacirignola, C. 1995. Water crisis in the Mediterranean, agricultural water demand management. Water Int. 20,176187.

Hayward, H.B., Long, E.M. 1941. Anatomical and physiological responses of the tomato to varying concentrations of sodium chloride, sodium sulphate and nutrient solutions. Botanical Gaz. $102,437-462$.
Liu, T., Van Staden, J. 2001. Growth rate, water relations and ion accumulation of soybean callus lines differing in salinity tolerance under salinity stress and its subsequent relief. Plant Growth Regul. 34,277-285.

Loulakakis, K., Roubelakis-Angelakis, K., Kanellis, A. 1994. Regulation of glutamate dehydrogenase and glutamine sythetase in avocado fruit during development and ripening. Plant Physiol. 106, 217-222.

Lowry, O., Rosebrough, N.J., Farr, A.L., Randall, R.J. 1951. Protein measurement with the Folin phenol reagent. J. Biol. Chem. 193, 265-275.

Meliou, E., Magiatis, P., Skaltsounis, A.L. 2003. Alkylresorcinol derivatives and sesquiterpene lactones from Cichorium spinosum. J. Agr. Food Chem. 51, 1289-1292.

Mittler, R. 2002. Oxidative stress, antioxidants and stress tolerance. Trends Plant Sci. 7,405-410.

Munns, R., Termaat, A. 1986. Whole plant response to salinity. Aust. J. Plant Physiol. 13,143-160.

Nair, A., Ngouajio, M., Biernbaum, J. 2011. Alfalfabased organic amendment in peat-compost growing medium for organic tomato transplant production. HortScience, 46, 253-259.

Nieman, R.H., Clark, R.A., Pap, D., Ogata, G., Maas, E.V. 1988. Effects of salt stress on adenine and uridine nucleotide pools. J. Exp. Bot. 39, 301-309.

Niu, X., Bressan, R.A., Hasegawa, P.M., Pardo, J.P. 1995. Ion homeostasis in $\mathrm{NaCl}$ stress environments. Plant Physiol. 109, 735-742.

Pardossi, A., Bagnoli, G., Malorgio, F., Campiotti, C.A., Tognoni, F. 1999. NaCl effects on celery (Apium graveolens L.) grown in NFT. Sci. Hortic. 81, 229-242. 
Savvas, D., Lenz, F. 1994. Influence of salinity on the incidence of the physiological disorder internal fruit rot' in hydroponically-grown eggplants. Angew Bot. 68, 32-35.

Shalhevet, J., Heuer, B., Meiri, A. 1993. Irrigation interval as a factor in the salt tolerance of eggplant. Irrigation Sci. 4, 83-93.

Simopoulos, A. 2004. Omega-3 fatty acids and antioxidants in edible wild plants. Biol. Res. 37, 263-277.

Song, J., Ding, X., Feng, G., Zhang, F. 2006. Nutritional and osmotic roles of nitrate in a euhalophyte and a xenophyte in saline conditions. New Phytologist. 171, 357-366.

Sonneveld, C. 2000. Effects of salinity on substrate grown vegetables and ornamentals in greenhouse horticulture. Ph.D. Dissertation. Wageningen University, Wageningen, The Netherlands, 151 pp.

Tzortzakis, N.G. 2009. Influence of $\mathrm{NaCl}$ and calcium foliar spray on lettuce and endive growth using nutrient film technique. Int. J. Veg. Sci. 15, 1-13.
Tzortzakis, N.G., Borland, A., Singleton, I., Barnes, J. 2007. Impact of atmospheric ozone-enrichment on quality-related attributes of tomato fruit. Postharvest Biol. Technol. 45, 317-326.

Ushakova, S.A., Kovaleva, N.P., Gribovskaya, I.V., Dolgushev, V.A., Tikhomirova, N.A. 2005. Effect of $\mathrm{NaCl}$ concentration on productivity and mineral composition of Salicornia europaea as a potential crop for utilization $\mathrm{NaCl}$ in LSS. Adv. Space Res. 36, 1349-1353.

Wignarajah, K., Jennings, D.H., Handley, J.F. 1975. The effect of salinity on growth of Phaseolus vulgaris L. I. Anatomical changes in the first trifoliate leaf. Ann. Bot. 39, 1029-1038.

Zeghichi, S., Kallithraka, S., Simopoulos, A.P. 2003. Nutritional Composition of Molokhia (Corchorus olitorius) and Stamnagathi (Cichorium spinosum). In: Simopoulos AP, Gopalan C (eds): Plants in Human Health and Nutrition Policy. World Rev Nutr Diet. Basel, Karger, 2003, vol 91, pp 1-21. 